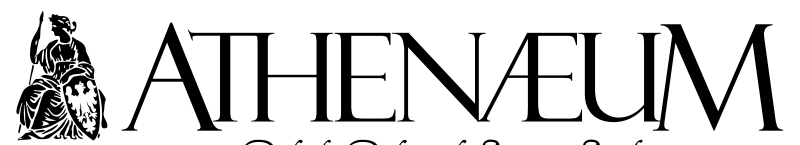

Polish Political Science Studies

Polskie Studia Politologiczne

vol. 67(3)/2020, pp. 154-173

DOI:10.15804/athena.2020.67.09

www.athenaeum.umk.pl

ISSN 1505-2192

(i) $\odot$

\title{
INTERNAL MIGRATIONS FROM CRIMEA AND DONBASS AFTER 2014 AS CONFLICT-TRIGGERING FACTORS IN THE REGIONS OF UKRAINE
}

\author{
WEWNĘTRZNE MIGRACJE Z KRYMU I DONBASU PO 2014 \\ ROKU ORAZ ICH WPŁYW NA POTENCJAŁ KONFLIKTOGENNY \\ W REGIONACH UKRAINY
}

Oksana Voytyuk*

\begin{abstract}
The annexation of the Crimea and the war in Donbass resulted in intense migration flows from these areas to the non-conflict areas of Ukraine. Internally displaced persons (IPDs) in the initial phase of the conflict were mainly received by the neighbour regions bordering with the area affected by the conflict. The endless war in Donbass significantly affected the deterioration of the economic situation in Ukraine, which also influenced the attitude towards IDPs. The social attitude towards IDPs from Donbass was initially positive, but gradually changed into negative one, mainly in the eastern Russian-speaking regions of Ukraine. In the west of the country, the attitude was more positive. The main factor that could reduce the degree of tension in the society between IDPs and the receiving communities is the end of the war in Donbass, but as the situa-
\end{abstract}

- ABSTRAKT -

Aneksja Krymu i wojna w Donbasie spowodowały intensywne migracje wewnętrzne $\mathrm{z}$ tych obszarów do regionów nie objętych konfliktem. Osoby wewnętrznie przemieszczone (OWP) w początkowej fazie konfliktu głównie przemieszczały się $\mathrm{w}$ sąsiednie regiony graniczące z obszarem dotkniętym konfliktem. Niekończąca się wojna w Donbasie znacząco wpłynęła na pogorszenie się sytuacji gospodarczej na Ukrainie, co również wpłynęło na stosunek do osób wewnętrznie przesiedlonych. Społeczne podejście do OWP z Donbasu było początkowo pozytywne, ale stopniowo zmieniło się w negatywne, głównie we wschodnich, rosyjskojęzycznych regionach Ukrainy. Na zachodzie kraju postawa była bardziej pozytywna. Głównym czynnikiem, który może zmniejszyć stopień napięć w społeczeństwie między osobami wewnętrznie przesiedlonymi

* University in Białystok, Institute of History and Political Sciences. 
tion of the conflict indicates, it cannot be finished quickly. a społecznościami przyjmującymi, jest koniec wojny w Donbasie, ale jak pokazuje sytuacja, nie można liczyć na szybkie zakończenie konfliktu.
Keywords: Internally Displaced Persons (IDPs); internal migration; Donbass; Ukraine
Słowa kluczowe: osoby wewnętrznie przesiedlone (OWP); migracja wewnętrzna; Donbas; Ukraina

\section{INTRODUCTION}

The annexation of Crimea and the war in Donbass contributed to the emergence of the phenomenon of internal migrations and to the appearance of internal refugees or internally displaced persons (IDPs). Unlike refugees, the IDPs are legally protected by the government of Ukraine. In 2014, the Supreme Council of Ukraine adopted the law On Guaranteeing the Rights and Freedoms of Internally Displaced Persons, according to which the IDP was "a citizen of Ukraine, a foreigner or stateless person, residing legally on the territory of Ukraine and entitled to permanent residence in Ukraine, who had been forced to leave the place of residence in order to avoid the negative effects of armed conflict, temporary occupation, ubiquitous acts of violence, violation of human rights and natural or man-made disasters" (Law of Ukraine, 2015).

As warfare developed in the east of Ukraine there were several waves of migration, both internal and external (Voytyuk, 2018a, pp. 359-362). In addition, the annexation of Crimea also favoured the development of the intensity of this phenomenon.

Migrations from the occupied territories caused a number of problems in regions that were not affected by the conflict. The most common problems were:

- different attitudes towards the IDPs from Crimea and Donbass,

- tensions between the IDPs and host communities,

- increase of conflict-triggering potential in regions of Ukraine,

- adaptation problems.

Before analysing the problem of internal migration, a few words need to be said about the specificity of Donbass and Crimea. The history of Crimea was long and dramatic, because the fate of many nations intersected there (From the Cimmerians, 2010). In various historical periods the peninsula was a part of the Golden Horde, an independent state (Crimean Khanate, 1449-1783), in vassal dependence on the Ottoman Empire (after the death of Haji Girei and until 
the annexation in 1783), part of the Russian Empire (from 1783), later Soviet Russia, and in 1954, the peninsula became part of the Ukrainian Soviet Socialist Republic (Vozgrin, 2013, vols. 1-4). In 1991, after the collapse of the USSR, the Crimean peninsula was included into the independent Ukrainian state, and its status was not regulated during the first years of Ukraine's independence.

In March 2014, Crimea was unlawfully annexed by the Russian Federation. Despite the fact that the peninsula de facto was considered Ukrainian since 1954, the influence of Kyiv was negligible, and the Russian influence was never eradicated and only increased in the last years before the annexation (Zadorozhnyi, 2015).

In the interwar period, the Crimean Tatars were the largest ethnic group in Crimea. After the Second World War and the deportation of the Crimean Tatars to Central Asia, their place was taken mainly by Russians, and to a lesser extent Ukrainians (Vozgrin, 2013, Vol. 4). Most of the peninsula's population used to be mainly Russian-speaking, and in political, socio-cultural preferences, they were more inclined to Russian than Ukrainian, except for the Crimean Tatars and Ukrainians.

The history of Donbass is slightly different from the history of Crimea, because in the interwar period Ukrainians dominated in this region (Voytyuk, 2018a, pp. 125-138). The ethnic structure in Donbass as well as in the Crimea began to change after the Second World War. The processes of industrialization of Donbass were strengthened by the Russification policy, which significantly increased the number of Russians in the ethnic structure of the region. Donbass began to lose Ukrainianness in favor of Russianness. Since then, this region has always held a pro-Russian position in political preferences and in the cultural and social aspect. Russian culture, language and traditions were closer to the citizens of the region than Ukrainian values (Voytyuk, 2018).

Linguistic, religious and cultural differences have divided the inhabitants of the east and the west of Ukraine since the proclamation of independence in August 1991. The western part of the state can certainly be said to be the core of Ukrainianness - here the Ukrainian language has always prevailed, the west is very diverse in religious terms (Orthodox, Greek, Roman Catholic, Protestants). On the east and in the Crimea the influence of the Russian Orthodox Church was strong. The Crimean Tatars after returning to the Crimea in 1991 began the revival of Islam.

Inhabitants of the east and the west of Ukraine also differ in terms of political preferences - the east Ukraine and Crimea (except for the Crimean Tatars) have always supported pro-Russian forces, while the west - pro-European and 
nationalist forces. No less important are economic differences - eastern Ukraine has always been the centre of industry, Crimea - a strategic place, while the west was dominated by the service and agricultural sectors (Putintsev \& Pashchenko, 2015).

According to statistical figures, at the beginning of 2018 there were 1493 529057 IDPs. Considering the data included in Table 1, the biggest number of IDPs was received by the regions in the direct vicinity of the occupied Crimea and ATO (Anti-Terrorist Operation Zone) area - the Donetsk Oblast (588 100), the Kharkiv Oblast (191 700), Zaporizhia Oblast (102 500), the Dnipropetrovsk District (73 800), and Kyiv (153 400). The lowest IDP number arrived in the Chernivtsi Oblast (3000), the Ternopil Oblast (2700), and the Volyn Oblast (3800). It was the Lviv Oblast that received the biggest IDP number of all Western Ukraine districts (10 400), and Lviv itself was a shelter to about 8000 people. The fact the people concentrated in the areas of direct vicinity to ATO zone and Crimea could be explained by people's expectations of war to be soon ended and Crimea de-occupated. The unfavorable attitudes towards western regions in the initial stage of the conflict could be explained by numerous stereotypes and convictions of nationalist and hostile societies.

Table 1. The Number of IDPs in 2015-2018 from Occupied Territories

\begin{tabular}{|l|r|r|r|r|}
\hline Oblast/Date: & $\mathbf{2 5 . 0 9 . 2 0 1 5}$ & $\mathbf{0 4 . 0 2 . 2 0 1 6}$ & $\mathbf{0 3 . 0 8 . 2 0 1 7}$ & $\mathbf{0 1 . 0 2 . 2 0 1 8}$ \\
\hline Volyn Oblast & 3800 & 4033 & 2824 & 2906 \\
\hline Lviv Oblast & 10400 & 11337 & 12050 & 12013 \\
\hline Zakarpattia Oblast & 3300 & 3462 & 3467 & 3599 \\
\hline $\begin{array}{l}\text { Ivano-Frankivsk } \\
\text { Oblast }\end{array}$ & 3900 & 4116 & 3397 & 3493 \\
\hline Chernivtsi Oblast & 3000 & 3149 & 2263 & 2500 \\
\hline Ternopil Oblast & 2700 & 2722 & 2499 & 2189 \\
\hline Rivne Oblast & 3100 & 3204 & 3256 & 3219 \\
\hline Khmelnytskyi Oblast & 7100 & 6793 & 6584 & 6988 \\
\hline Vinnytsia Oblast & 12400 & 13251 & 14819 & 14902 \\
\hline Zhytomyr Oblast & 9800 & 10496 & 7270 & 7248 \\
\hline Kyiv & 153400 & 127026 & 153999 & 159412 \\
\hline Kyiv Oblast & $\mathrm{b} / \mathrm{d}$ & 48318 & 59926 & 62042 \\
\hline Cherkasy Oblast & 14000 & 48318 & 12964 & 12643 \\
\hline Kirovohrad Oblast & 10600 & 12268 & 7801 & 6854 \\
\hline
\end{tabular}




\begin{tabular}{|l|r|r|r|r|}
\hline Oblast/Date: & $\mathbf{2 5 . 0 9 . 2 0 1 5}$ & $\mathbf{0 4 . 0 2 . 2 0 1 6}$ & $\mathbf{0 3 . 0 8 . 2 0 1 7}$ & $\mathbf{0 1 . 0 2 . 2 0 1 8}$ \\
\hline Odessa Oblast & 31800 & 35703 & 38095 & 39873 \\
\hline Mykolaiv Oblast & 8500 & 8612 & 8255 & 8350 \\
\hline Kherson Oblast & 12900 & 14226 & 13441 & 13760 \\
\hline Dnipropetrovsk Oblast & 73800 & 76457 & 73576 & 73630 \\
\hline Zaporizhia Oblast & 102500 & 118878 & 54564 & 54174 \\
\hline Poltava Oblast & 29300 & 30684 & 27502 & 25903 \\
\hline Sumy Oblast & 14900 & 15283 & 14299 & 11102 \\
\hline Kharkiv Oblast & 191700 & 212557 & 160616 & 122396 \\
\hline Luhansk Oblast & 223100 & 251231 & 299134 & 294529 \\
\hline Donetsk Oblast & 558100 & 676553 & 529130 & 540804 \\
\hline Chernihiv Oblast & 9500 & 10011 & 8614 & 8528 \\
\hline Totally: & 1493600 & 1748688 & 1520345 & 1493057 \\
\hline
\end{tabular}

Source: author's own study based on infographics in Slovo i dilo (2017).

\section{MATHERIALS AND METHODS}

The purpose of this article is to present the analysis of the reasons forcing people to flee from the occupied territories and the territories affected by the conflict, relations between IDPs and the receiving communities in different parts of the state. In the context of the analysis of the phenomenon of internal migration, the question should be answered whether the reasons for leaving Donbass and the Crimea are similar or not? Is Ukrainian society really divided into east and west? Is there a chance that the war in Donbass and the annexation of Crimea will eliminate social divisions, if any?

The article was written following the analysis of the figures and reports of sociology institutes, non-governmental and international organizations (Report, 2019; OSCE, 2017; IEF, 2019). The main attention was concentrated on the following reports: Assessment of Psychological, Socio-Economic Adaptation and Integration of IDP Women in New Communities (Vinnytsya, Lviv and Kyiv oblast'). The document provides an assessment of the various problems faced by IDP women. It analyses how women adapt to new living conditions. What are the opportunities for the interaction between IDPs, local authorities and host communities (OSCE, 2017). In the report IDPs and Host Communities: Lessons for Effective Community Adaptation and Integration, the following aspects were 
analysed: international experience in public policy making regarding IDPs and the approaches to assessing their integration and adaptation. The functions and opportunities of state authorities, local authorities, private and public sectors, rural communities in these processes in Ukraine were considered. The manifestations and factors of social exclusion among IDPs have been identified. The correlation of different forms of social capital of IDPs in Ukraine was analysed and the determinants of their successful local integration were substantiated. The expectations of the representatives of host communities regarding the IDPs were established, the value differences of IDPs and the representatives of the host communities were analysed on this basis. The set of practical recommendations on the expedient directions of the state policy on adaptation and integration of IDPs in Ukraine was offered (IEF, 2019). The report Analysis of the Dynamics of Conflicts between the IPDs and Host Communities 2014-2016 was a significant source while writing the article. It is based on a survey of over 117 regional experts, NGO leaders, as for their opinion on IDPs in host communities. It was also analysed how the issues related to IDPs as well as the attitude of the local population to the IDPs were presented in the media (Stabilization Support Services, 2017). Report The Attitude of the Population of Ukraine to IDPs from Donbass and Crimea: Results of the Public Opinion Polls 2015-2018 presents the dynamics of changes in population attitudes towards IDPs and assesses the subjective integration potential for IDPs in host communities. Questions about the attitude of the population to IDPs, in particular, the willingness of the local population to interact with displaced persons at the private, professional and public levels, were asked to respondents in 2015-2018 in all regions of Ukraine except the Crimea and the occupied territories of Donetsk and Luhansk regions. Each year, 1800 respondents over the age of 18 were interviewed (UNCHR, 2019). In the Report on the Results of Analysis of the Problems of IDP in the United Territorial Communities the key issues of IDPs in host communities were summarized. Prospects of integration of IDPs into integrated territorial communities are the possibilities of taking into account the policy of decentralization when developing a strategic plan for IDPs' integration. The achievements and problems of the integrated territorial communities in integrating IDPs were analysed, the ability to implement and promote the social protection policies of IDPs were considered (Radnyk, 2017-2018). The research was conducted in the following regions of Ukraine: the Vinnytsia Oblast, the Zaporizhia Oblast, the Poltava Oblast, the Ivano-Frankivsk Oblast, the Donetsk Oblast, the Luhansk Oblast, the Kherson Oblast, the Lviv Oblast, the Kyiv Oblast, and in Lviv. The 
reports show that during the adaptation of internally displaced persons in places of new residence, the main attention is focused on economic, psychological, sociological, demographic, anthropological and medical aspects. In this context, medical science focuses on the quality of the health of IDPs, on the frequency of various diseases, including epidemies. Psychological sciences consider the psychological conditions of internally displaced persons, including stress and their behavioural consequences. For sociology and anthropology, the interactions of internally displaced persons with the new cultural environment and the possibility of transforming the identity of internally displaced persons are the major problems. Economics is relatively more interested in the costs and working potential, qualifications of internally displaced persons, as well as their experience/abilities (Putintsev \& Pashchenko, 2015).

The monograph by S. Kulchyts'kyy and L. Yakubova, Three Hundred Years of Loneliness: Ukrainian Donbass in Search of Meaning and Homeland (2016), was a useful publication helping to understand the reasons between IDPs and hosting communities. The monograph presents the circumstances of the colonization of the Donetsk region and the Luhansk region, and analyzes the participation of individual ethnic groups in the economic development of the region, the processes of ethno-cultural interaction and the contradictions they generated (Kulchyts'kyy \& Yakubova, 2016). The important inspiration while writing the article was also the research of Illiya Kononov, where not only he analyses the relations between the center and the provinces, but also between two regional poles, namely Donbass and Galychyna, that produce different perspectives on social development (Kononov, Khobta, \& Shchudlo, 2008; Kononov, 2019).

Different problems that concern the history of Crimea were introduced in monographs by V. Vozgrin, The History of Crimean Tatars: Essays on the Ethnic History of the Indigenous Population of Crimea (2013), by O. Zadorozhnyi, Annexation of Crimea Is an International Crime (2015), and by O. Voytyuk, Tatarzy Krymscy. Sytuacja narodu w warunkach zmieniajacych się państwowości [Crimean Tatars: The Situation of the Nation in the Conditions of Changing Statehood] (2018). Among the research problems were the relations between some ethnic groups, deportation of 1944, the annexation the peninsula in 1783 and in 2014, fight for human rights. Monographs helped to understand the history of Crimea and Donbass before 2014, and to find differences among Ukrainian regions and understand them.

In the context of internal migrations from Donbass and the Crimea, two theoretical approaches can be distinguished - socio-cultural and economic. 
In this context, the IDPs adaptation to new realities is very important. From the point of view of the socio-cultural approach, adaptation is overcoming the shock of changing the ordinary cultural environment and the need to adapt to another culture, including finding the way of successful coexistence between internally displaced persons with those of surrounding groups. The essence of the economic approach is that "Resources can be defined as the means by which people meet needs, pursue goals and meet requirements". In the context of the IDPs, there are factors that facilitate or limit the access to resources (Putintsev \& Pashchenko, 2015).

Basically, the following dimensions of IDP's adaptation can be distinguished:

- as part of the socio-cultural approach, this is to overcome psychological stress caused by moving to a new place of residence;

- as part of the economic approach, adaptation consists in obtaining information on the availability and location of the new place of residence of the resources needed to maintain "livelihoods" (housing, food, income sources (taxes, business income, social payments), healthcare, education, transport and communication, etc.) (Putintsev \& Pashchenko, 2015).

The theory proposed by J.T. Gullahorn and J.E. Gullahorn can be used to evaluate IDP adaptation strategies. It is based on the hypothesis that the adaptation follows a certain U-shaped curve, the individual parts of which reveal the stages of this process:

- the first stage, characterized by optimistic expectations and hopes for the future;

- the second stage is characterized by an increase in the negative impact of the environment on the person, which causes a state of depression and frustration;

- the third stage is characterized by the maximum manifestation of symptoms of helplessness and the appearance of psychosomatic disorders;

- the fourth stage is accompanied by the appearance of optimism, a sense of satisfaction and integration in new conditions;

- the fifth stage ends with the complete adjustment of the unit.

According to reports, some IDPs are unable (or reluctant) to fully adapt to the new environment and return to their previous place of residence after the relative normalization of the situation. There, they encounter the new problems of readaptation, which again repeat the U-curve (Gullahorn \& Gullahorn, 1963, pp. 33-47). 


\section{INTERNALLY DISPLACED PERSONS FROM THE CRIMEA}

The events that took place on February 26, 2014 were a breakthrough moment in the history of Crimea that commenced a creeping occupation of the peninsula. Masked soldiers in unmarked green army uniforms, carrying modern Russian military weapons and equipment (also called "Little Green Men"), appeared in the streets of Crimean towns, and the chaos they brought, as well as increasing ethnic and religious discrimination contributed to direct danger experienced by certain social groups. The first migrations from the Crimea began.

Initially, the reasons to leave Crimea were based on ideological terms: strong pro-Ukraine stance, the unwillingness to accept new conditions imposed by the occupants; then - unbearable life conditions to pro-Ukrainian population regardless ethnic affiliation (bad atmosphere, no perspectives, demonstration of negative attitudes, businesses being endangered, persecution, denouncing people to the authorities, aggression, physical violence, abduction, arrest, searching with no relevant reason, intimidation). The clergymen, the Crimean Tatars, Crimean Ukrainians and other ethnic groups started to leave the peninsula. Economic factors were not significant in this situation.

Lviv and Kyiv were the first cities ready to receive IDPs from Crimea. Kyiv provided shelter to a nationally diverse group of people, since not only the Crimean Tatars came here, so did Crimean Ukrainians and other ethnic groups that did not feel safe after the annexation of Crimea. The group of IDPs chose Kyiv, as they wanted to be close to the state structures that were created in order to solve IDP problems (Ministry of Temporarily Occupied Territories). IDPs expected to receive faster state's help in Kyiv in solving their problems.

However, it was Lviv that received the biggest IDP number in March-April 2014. The Crimean Tatars were invited to Lviv by the oblast administration and the mayor of Lviv, Andrii Sadovyi. The inhabitants of Lviv treated the Crimean Tatars with understanding and they were willing to help them (Radio Svoboda, 2014).

The Crimean Tatars were distinguished, being compared to the IDPs from Donbass, by the following factors:

- They actively used survival strategies they had acquired during the deportations and exile in 1944-1989;

- When they moved to Lviv from other regions of Ukraine, they were not afraid to establish active interactions with the state, the NGOs and the voluntaries. They were frequently the initiators of voluntary organizations themselves; 
- They managed to solve their job problems independently, by settling their own businesses (ethnic cuisine, handicraft, NGOs);

- They created ethnic-cultural associations;

- They supported one another, helping people arriving from the Crimea later.

As the statistical data prove, there is a big difference in the approach to the Crimean Tatars and the IDPs from Donbass in the Ukrainian society. Perception of the Crimean Tatars and attitude towards this group within the Ukrainian society is different from opinions on the IDPs from Donbass. The influence of mass media on public opinion in this context seems to be critical (Graph 1).

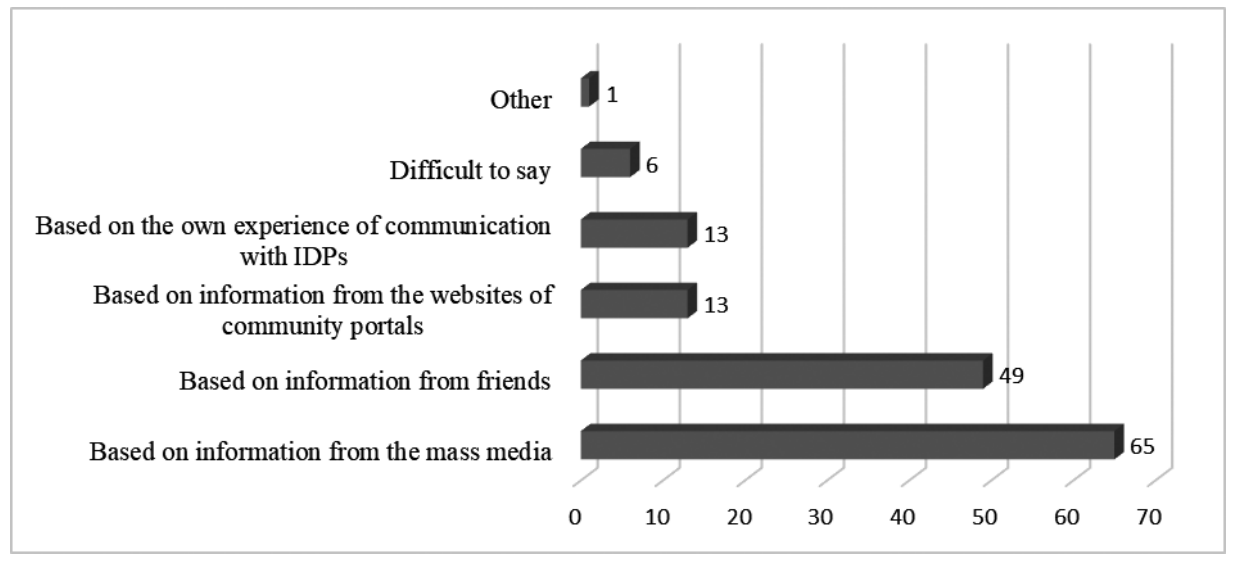

Graph 1. On Which Sources of Information Is Your Opinion on IDPs Formed? Source: author's own translation on the base of Attitude, 2016, p. 10.

According to the statistical data, 65 per cent of the Ukrainians formed their opinion on IDPs following the media information, 49 per cent formed the opinion according to their friends' information, 13 per cent received the information from social media, 13 per cent used their own experience. The United Nations High Commission for Refugees reports that the Crimean Tatars are more liked in the west of Ukraine - 11 per cent, in the center - 9 per cent, and in the capital - 12 per cent. The level of confidence to the Crimean Tatars is higher, as this nation explicitly declared their standpoint related to Crimea annexation and the policy of the Russian Federation.

Positive attitude of the society in Western Ukraine towards the Crimean Tatars results from the similar past experience among people living in the 
western regions of Ukraine, particularly the deportations among the present inhabitants of Western Ukraine from eastern Poland. The dramatic experience they shared became the grounds for positive feelings, support and understanding the problems experienced by the Crimean Tatar people. The Crimean Tatars' reasons for choosing western Ukraine and Lviv include such factors as friendly and religious people living here, helpful while looking for a job and accommodation. Their attitude towards poor competence of the Ukrainian language among the newcomers is full of understanding. In fact, the Crimean Tatars are willing to study Ukrainian language and use it in their everyday life along with Crimean Tatar language. Local population's positive approach to the Crimean Tatars results from their pro-Ukrainian stance (Mikheyeva \& Sereda, 2015, pp. 9-49).

There were several stages in the Crimean emigration during the short period after the annexation of the peninsula. There was the main reason of emigration in each stage but the reasons appearing earlier also need to be considered. However, the main reason to leave the Crimea just after Russian annexation was the one of the ideological nature. The first group to leave the Crimea were military men and women who had made the oath of allegiance to Ukraine and Ukrainian people; they were followed by the government administration, journalists, patriotic activists and the clergy who did not accept the annexation. Most of them left the peninsula in fear of their and their families' security. Considering the clergy, these who left were the representatives of the religious factions that were illegal in Russia and the representatives of other religious minorities - the Ukrainian Orthodox Church, protestants, Greek Catholic. The first stage of emigration covered the period from March to the summer of 2014. In the summer, when it turned out there would be no war, the migration movement stopped. Some people returned to the peninsula, yet the majority sold their property in the Crimea and decided to stay in the continent.

Since the very beginning of the Crimea occupation the forced emigration based on discrimination has continued. It is mainly related to the Crimean Tatars (the Mejlis members) and these Ukrainians who did not leave the Crimea at the beginning of the occupation for various reasons. These groups are treated in a way making them leave the peninsula (their houses being searched, persecution, harassment, criminal proceedings).

The second stage of emigration from the Crimea began in the autumn of 2014, being mainly motivated economically. In September and October 2014, young educated and professionally active people began leaving the Crimea. Their 
political preferences were diverse yet Ukrainian patriotic attitudes formed a critical factor of their decisions. They initially believed it was possible to co-exist with the new authorities; however, it turned out to be impossible. There are no accurate data concerning the number of people who moved to the continent, as unlike during the first emigration stage in the spring, they did not officially register. The estimated data proved the smaller number of newcomers during the second emigration stage - they accounted for 30 per cent emigrants of the first stage (Drozd, 2014). The migrations slightly ceased in the winter of 2014/2015 due to the fear of homelessness, lack of jobs and money.

Educational migration (the third stage) intensified in the summer of 2015, when young people decided to travel to Ukraine in order to gain access to higher education. According to Emine Dzheparova, the First Deputy Minister of Information Policy, "Ukrainian education for Crimeans is a guarantee for return of the Crimea to Ukraine" (Uryadovyi kurier, 2016). For the Crimean youth there are two possibilities to enrol at Ukrainian Higher Educational Institutions:

- Considering the results of final state examination. The documents can be submitted to all Ukrainian higher educational institutions on a par with other Ukrainian citizens;

- Following the simplified procedure not considering the results of final state examination (there are students in the Crimea who did not have the possibility to take this exam). Students are obliged to pass such subjects as Ukrainian language, history and literature in Educational Centers "Crimea - Ukraine" (Lvivska gazeta, 2016) ${ }^{1}$.

When it was realized that improving situation in the Crimea was nothing more than illusion, the fourth stage of emigration began, the stage of a business nature. Small and medium-sized businesses in the Crimea were based on tourism and travel-related services, like catering, tourist guide services, rentals for tourists, etc. Russian government strictly limited businesses in seaside regions, partly destroying infrastructure in coastal areas. Moreover, the Crimea annexation resulted in the considerable loss in the number of tourists, which made the hotels and pensions unprofitable and cost-consuming. Furthermore, conditions to run business became highly unfavorable, which resulted in moving a part of

1 In July 2016 the educational centers "Crimea-Ukraine" were opened in 12 Ukrainian higher educational institutions. Their purpose is to test the Crimean youth and help them enrol at Ukrainian higher educational institutions. The centers were established in Lviv, Kyiv, Kherson, Dnipro, Zaporizhia, Mykolaiv, and Kharkiv. The centers are also obliged to help the youth to apply for the Ukrainian passport. 
businesses in the coastal regions of Ukraine, such as Odessa Oblast, Mykolaiv Oblast, or Kherson Oblast.

Conscription emigration was the fifth stage of emigration. It was related to compulsory military service in Ukraine, compulsory military conscription. There are concerns that people who achieved military age could be dispatched to eastern Ukraine in order to support the rebel forces in Donetsk and Lugansk (Hromadske Radio, 2014). Certain part of people in the Crimea arrived in Ukraine where they joined the Armed Forces of Ukraine.

\section{INTERNALLY DISPLACED PERSONS FROM DONBASS}

Internally Displaced Persons from Donbass are in a slightly worse situation than the Crimean Tatars. There were a lot of reasons contributing to this condition. As it was mentioned above, during the first migration stage it was a patriotic attitude and a pro-Ukrainian standpoint that made the Crimean Tatars leave the Crimea, whereas in Donbass these were the rich who fled as the first group, hoping to save their ships. Most of them did not stay in Ukraine and using various excuses decided to move to Europe, Russia, or Belarus. Later, the main reason to leave Donbass was the hostilities, making IDPs lose their property and endangering their life and health. People residing in other regions of Ukraine perceived IDPs from Donbass to be the ones supporting separatism. According to UNHCR Report, the positive attitude to IDPs from Donbass in the east of Ukraine reached 7 per cent, while in central Ukraine, western Ukraine and Kyiv it did not exceed 4 per cent (Attitude, 2016, p. 12).

Considerable part of IDPs from Crimea is formed by families with children. Unfortunately, there was no access to more precise data to present it in a chart. In the media, the image of IDPs from Donbass is unfavorable, being formed by the security services that focus on the negative phenomena and deeds within this group (e.g., the increase in crime in different regions is associated with IDPs) (Panchenko, 2017).

The statistical data prove that the retired constitute the biggest group among IDPs -52.5 per cent, while the group of professionally active IDPs constitutes only 28 per cent, children - 15.5 per cent, the disabled - 4 per cent (Graph 2). Most of these people need social security support, such as benefits or pensions.

The Ukrainian government suspends pensions to the people who moved to non-government controlled areas and stayed there more than two months, 
until they return to government-controlled areas. The number of these people approximately reaches as many as 500,000 (Interfax UA, 2017).

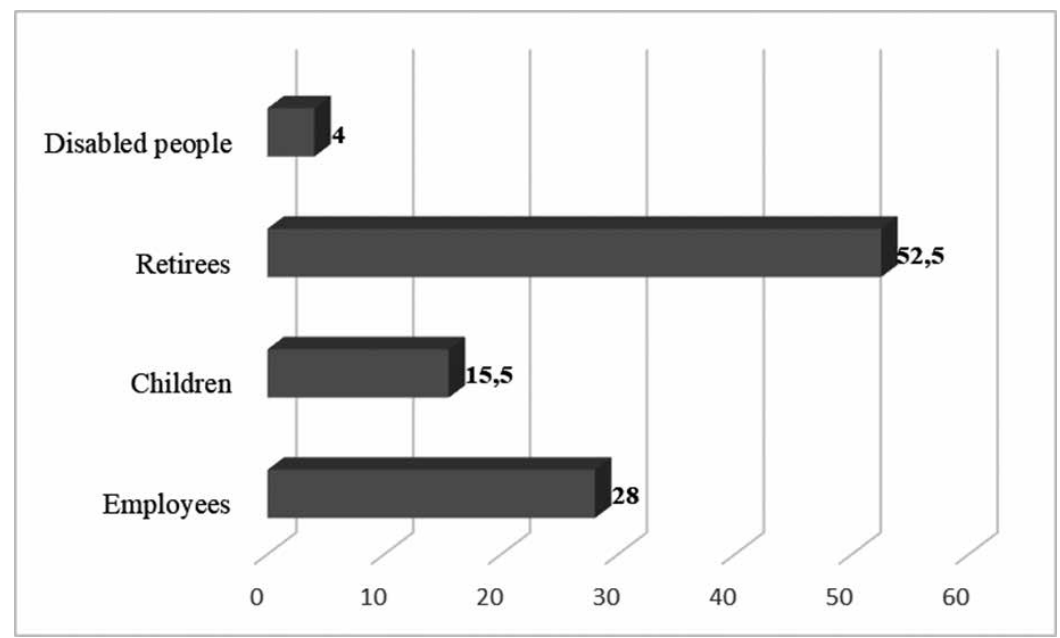

Graph 2. IDPs Age Structure, Including the Disabled Per Cent

Source: UAIN, 2018.

Occupation of Donbass and the Crimea resulted in negative attitudes to one another within the societies of these regions, including the noticeable differences. In the Crimea, it is mainly ethnic hostility between the Crimean Tatars and Ukrainians on one side and the Russians and pro-Russian citizens on the other. Then - the differences related to religion need to be mentioned, Muslim versus Orthodox Christian. The third place is occupied by the supporters and the opponents of "the Russian World". In Donbass the circumstances are different - it is the ideology that matters: Donetsk People's Republic (DPR or DNR) and Luhansk People's Republic (LPR or LNR) supporters and opponents; ethnic and religious issues do not matter much.

Migration processes concerning leaving from the occupied Crimea and Donbass were also different. As it was mentioned before, the biggest migrant wave from the Crimea was observed just after it was annexed, during the first several months. The nature of the first wave was clearly ideological. The process of leaving Donbass was so intense that people just waited for the situation to improve, no matter what direction it could have chosen. Part of the inhabitants looked forward to being incorporated by Russia, like the Crimea was. However, the situation turned out to be different - it became obvious that the Russian Fed- 
eration was not interested in the annexation of Donbass. When the situation had become envenomed, people began fleeing from the occupied territories. Apart from ideological issues, people delayed moving from Donbass due to various reasons, such as the unwillingness to abandon their jobs, fears and stereotypes, mistrust, problems related to employment and accommodation in a new place.

The direction also was a significant matter. The Crimean Tatars opted for Lviv and Kyiv due to patriotic reasons, not considering employment and accommodation factors to be really critical. In particular situations, they considered their relatives residing in certain areas to be a favorable factor, it did not play the decisive role to them, though. The IDPs from Donbass, by contrast, regarded the fact their relatives stayed out of Donbass as a decisive factor. The other important element was employment. The patriotic reasons were not considered to be the ones of great importance (Petryk, 2018).

The Crimean Tatars and their families tended to emigrate on their own, their received the assistance having arrived in a particular place. The IDPs leaving Donbass could be divided into two groups: the IDPs whose departure was organized - these were mainly the employees of large enterprises, the members of religious communities or the IDPs leaving on their own (the families). The first IDP group was in a slightly more favorable situation, as they were given the basic assistance (temporary accommodation, sometimes employment); the other group often left Donbass during the shelling of the area. Having fled from the occupied territory, people were often forced to rely on themselves.

\section{CONFLICT-TRIGGERING POTENTIAL IN PARTICULAR REGIONS}

In January 2017, the conflict dynamics between the IDPs and the representatives of receiving communities, the demobilized individuals from ATO zone and the families of dead soldiers in ATO zone was examined. It was proved that the level of confrontational tendencies in the communities receiving the IDPs was increasing (Graph 3).

There are numerous factors affecting the increase in conflict-triggering attitudes in the Ukrainian society - from myths and stereotypes present in certain regions to religious, political and linguistic issues. The increase in negative attitudes toward the IDPs is also the result of a difficult economic situation in Ukraine, reduced financial rewards, unemployment, low standard of living. Moreover, it is the media that frequently form unfavorable attitudes toward 
the IDPs in the receiving regions, accusing them of illegal activities or abusing humanitarian assistance. Furthermore, the media often contribute to forming IDPs' image as criminal elements.

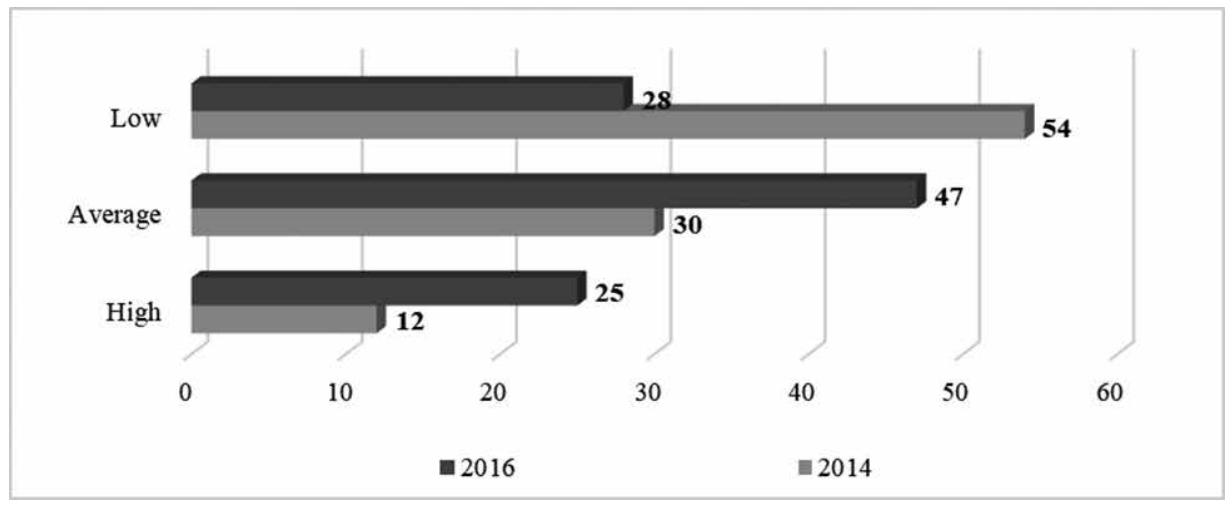

Graph 3. The Degree of Confrontation Tendencies in the Societies Receiving IDPs, 2014-2016

Source: own translation based on: Stabilization Support Services, 2017, p. 4.

A conflict-triggering potential in the Ukrainian society is going to increase; it will result from the additional assistance from the state, the charity organizations, the NGOs in the context of the decline in financial conditions and the increase in unemployment figures. Particularly negative attitudes toward IDPs are observed in regions along the demarcation line in Luhansk Oblast, Donetsk Oblast, Kharkiv Oblast, Kyiv Oblast and in the capital itself (Figure 1). The medium degree of confrontation tendencies is observed in the west and the south of Ukraine, in Volyn Oblast, Lviv Oblast, Zakarpattia Oblast, Odessa Oblast, Zaporizhia Oblast, Kherson Oblast, and Dnipropetrovsk Oblast.

This state of affairs could result from the fact that in the initial stage of the conflict people sympathized with IDPs, trying to help them. Now, the war has continued for 4 years, making people become used to daily reports from the frontline. Four years ago, these reports were perceived as the news of particular importance, while they seem to be quite common at present. Moreover, the IDPs do not always behave in an appropriate way, they tend to be demanding and arrogant (Stabilization Support Services, 2017).

Unless the war in Donbass finishes in a year or two, the standard of living will continue to be falling and social tensions will escalate, mainly between ATO and 


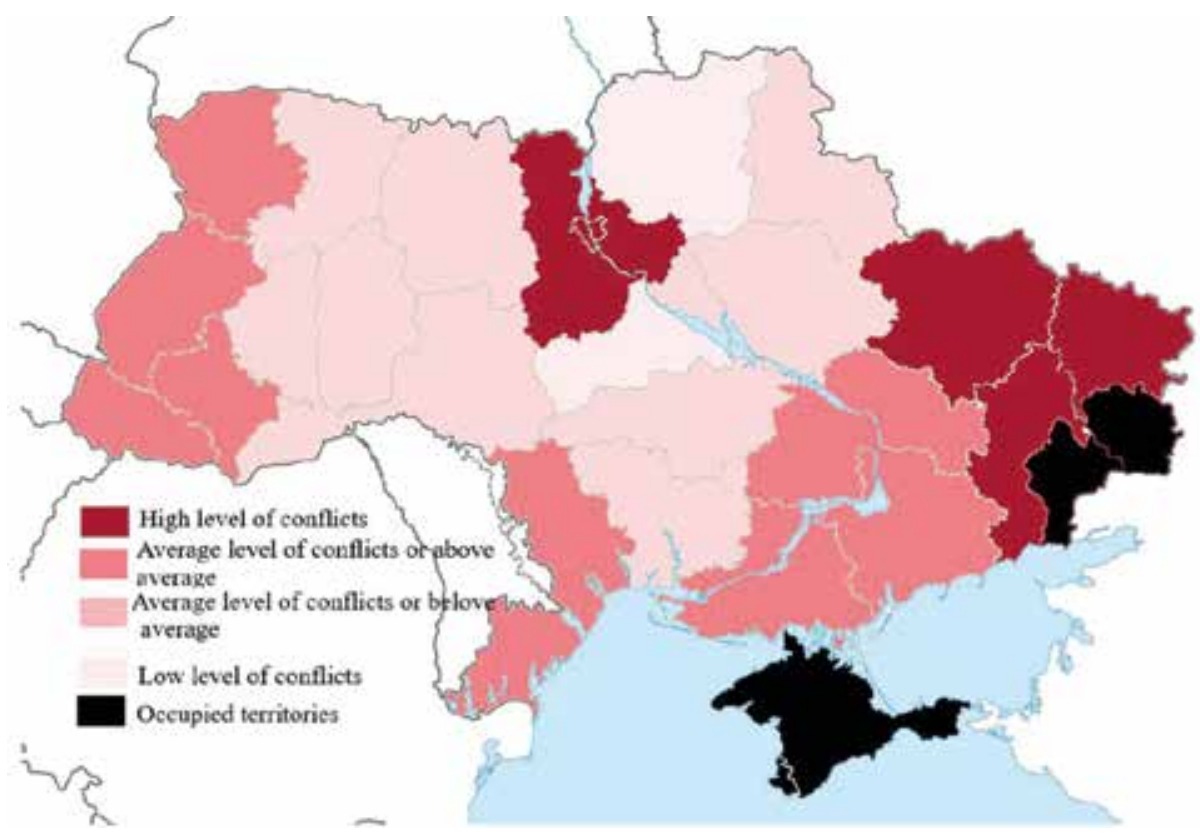

Figure 1. Conflict-Triggering Potential in Regions

Source: author's own study based on: Stabilization Support Services, 2017, p. 6.

their families and IDPs, concerning social benefits and assistance. Media will still play a leading role - the conflict-triggering potential will rise or fall depending on their rhetoric and the manner of conveying the news.

Another important problem is IDPs isolation (being the result of various reasons), their reluctance to get integrated, their unwillingness to learn the language as well as the rejection of Ukrainian lifestyle. Among the issues demanding to be solved soon is integration process among the soldiers coming back from ATO zone. Most of them are suffering from war traumas, often not being able to cope with them. The lack of psychological assistance and support, both to the soldiers and to the IDPs, might result in the tensions within these groups, leading to the increased level of aggression. Suicide attempts are a common consequence of inability to cope with the new reality. 


\section{CONCLUSIONS}

Migrations from the Crimea and Donbass resulted from different reasons. Migration from the Crimea was often independent in its nature, as the Mejlis of the Crimean Tatar people was regarded in the peninsula as an extreme organization and its leaders were prevented from entering the Crimea, thus not being able to provide any organized assistance. People from Donbass migrated on their own or in organized groups. Migration destinations were also different - the Crimean Tatars opted for the western regions of Ukraine, while the IDPs from Donbass tended to migrate to the regions neighbouring with the conflict zone, as they were afraid about not being accepted in the Ukrainian speaking regions. There were various factors affecting the degree of conflict tendencies in particular regions - political, religious and linguistic ones; before 2014, these factors were not so significant. Lowering the life standard both to IDPs and the receiving communities was also an important issue, so was the reluctance among the IDPs from Donbass to integrate, their certain alienation. The level of integration and self-organization among the Crimean Tatars in the receiving regions was noticeably higher. The major thing that could lower the tensions between the IDPs and receiving communities would be certainly the end of war in Donbass. This situation, however, is not likely to happen soon, so the degree of tensions in the Ukrainian society is going to increase along with lowered life standard of all social strata.

\section{ReFERENCES:}

Drozd, N. (2014, October 29). New Wave of Crimean Emigration. Retrieved from: http:// ru.krymr.com/content/article/26663847.html.

Gullahorn, J.T., \& Gullahorn, J.E. (1963). An Extension of the U-Curve Hypothesis. Journal of Social Issues, 19(3), 33-47. DOI: 10.1111/j.1540-4560.1963.tb00447.x.

Hromadske Radio (2014). Two New waves of Emigration from Crimea? - Andriy Klymenko. Retrieved from: http://hromadskeradio.org/2014/10/20/dvi-novi-hviliemigratsiyi-z-krimu-andriy-klimenko-black-sea-news/.

IEF (2019). IDPs and Host communities: Lessons for Effective Community Adaptation and Integration. Retrieved from: http://ief.org.ua/docs/en/295.pdf.

Interfax UA (2017, November 30). Half a Million Displaced Persons Returned to ORDLO Not Receive Pensions - Grymchak. Retrieved from: https://ua.interfax.com.ua/news/ general/465924.html (in Ukrainian). 
Kononov, I. (2019). Donbass and Galychyna in the Mirrors of Regional Consciousness (Focus Group Interview Materials). Methodology, Theory and Practise of the Social Analysis of the Modern Society, 15. Kharkiv: V.N. Karazin University.

Kononov, I., Khobta, S., \& Shchudlo, S. (2008). Donbass and Galychyna in the regional system of Ukraine. Sociology: Theory, Methods, Marketing, 3, 73-98.

Law of Ukraine (2015). On Ensuring the Rights and Freedoms of Internally Displaced Persons (Supreme Council (BD), 2015, No. 1, item 1). Retrieved from: https:// zakon5.rada.gov.ua/laws/show/1706-18.

Lvivska gazeta (2016, June 15). Children from the Occupied Crimea Will Be Able to Enter Ukrainian Universities without Testing. Retrieved from: http://www.gazeta. lviv.ua/2016/06/15/diti-z-okupovanogo-krimu-zmozhut-vstupati-do-ukrayinskixvishiv-bez-zno/.

Mikheyeva, O., \& Sereda, V. (2015). Contemporary Ukrainian Internally Displaced Persons: Key Causes, Resettlement Strategies and Problems of Adaptation. In: Stratehii transformatsii i preventsii prykordonnykh konfliktiv $v$ Ukraini. Zbirka analitychnykh materialiv [Strategies for Transformation and Prevention of Border Conflict in Ukraine: Collection of Analytical Materials] (pp. 9-49). Lviv: Galitska Publishing Union (in Ukrainian).

OSCE (2017). Assessment of the problems of psychological, socio-economic adaptation and integration of IDP women in new communities (Vinnytsia, Lviv and Kyiv oblasts). Retrieved from: https://www.osce.org/en/ukraine/303191?download=true.

Panchenko, Y. (2017, June 14). Our Refugees: Why the Problem of Settlers Is a Problem for All. Retrieved from: https://apostrophe.ua/ua/article/society/2017-01-14/nashibejentsyi-pochemu-problemyi-pereselentsev--eto-problemyi-vseh/9482.

Petryk, Kh. (2018). Oleg Kolysa: The Attitude to the Crimean Tatars in Lviv Is Good, to the IDP from East Is Bad. Retrieved from: http://tvoemisto.tv/exclusive/oleg_kolyasa_ do_krymskyh_tatar_u_lvovi_stavlyatsya_dobre_do_shidnyakiv_pogano_67418. html.

Putintsev, A., \& Pashchenko, Y. (2019). Adaptation of Internally Displaced Persons in Regions of Ukraine: Essence, Concepts, Approaches. Retrieved from: http://efm.vsau. org/files/pdfa/4543.pdf.

Radio Svoboda (2014, March 3). Crimeans Responded to the Invitation and Went to Lviv. Retrieved from: https://www.radiosvoboda.org/a/25283747.html.

Radnyk (2017-2018). Report on the Results of Analysis of the Problems of Internally Displaced Persons in the United Territorial Communities. Retrieved from: http:// radnyk.org/reports/problematic_idps/problematic\%20issues\%20related\%20to\%20 IDPs\%20in\%20ATC\%20report_radnyk_ukr.pdf.

Slovo i dilo (2017, June 19). In What Regions of Ukraine Live Internally Displaced Persons from the Occupied Territories. Retrieved from: https://www.slovoidilo. ua/2017/10/19/infografika/suspilstvo/yakyx-oblastyax-ukrayiny-prozhyvayutpereselenczi-okupovanyx-terytorij.

Stabilization Support Services (2017). Analysis of the Dynamics of Conflicts between the IDPs and Host Communities 2014-2016. Kyiv. 
Stratehii transformatsii i preventsii prykordonnykh konfliktiv $v$ Ukraini. Zbirka analitychnykh materialiv [Strategies for Transformation and Prevention of Border Conflict in Ukraine: Collection of Analytical Materials]. Lviv: Halych Publishing Union.

UAIN (2018, April 14). Valeriya Vershinina: The Number of Immigrants in Ukraine Is Decreasing. Retrieved from: https://uain.press/comments/valeriya-vershyninakilkist-pereselentsiv-v-ukrayini-zmenshuyetsya-787687.

UNCHR (2019, September 30). Attitude of the Population of Ukraine to Internally Displaced Persons from Donbass and Crimea: Results of the Public Opinion Polls. Retrieved from: https://dif.org.ua/article/stavlennya-naselennya-ukraini-dovnutrishno-peremishchenikh-osib.

Uryadovyi kurier (2016). Emine Dzhaparova: Ukrainian Education for the Crimeans - the Key to the Return of the Crimea. Retrieved from: http://www.kmu.gov.ua/ control/uk/publish/article?art_id=249137052\&cat_id=244277212.

Voytyuk O. (2018). Kilka uwag na temat stanu świadomości narodowej mieszkańców Donbasu. In: A. Furier (ed.). Ukraina - czas przemian po rewolucji godności (pp. 233-272). Poznań: FNCE.

Voytyuk, O. (2018a). Tatarzy Krymscy. Sytuacja narodu w warunkach zmieniajacych się państwowości. Białystok: Instytut Badań nad Dziedzictwem Kulturowym Europy.

Vozgrin, V. (2013). The History of Crimean Tatars: Essays on the Ethnic History of the Indigenous Population of Crimea. Vols. 1-4. Simferopol: Karadeniz production. Zadorozhnyi, O. (2015). Annexation of Crimea Is an International Crime. Kyiv: KIS. 